\title{
Atresia of the Coronary Sinus Ostium to the Right Atrium with a Persistent Left Superior Vena Cava
}

\author{
Atresia del Ostium del Seno Coronario en el Atrio Derecho \\ con una Vena Cava Superior Izquierda Persistente
}

*Abadio Gonçalves Caetano; "Tiago Coelho Ribeiro; *Omar Andrade Rodrigues Filho \& *,***aléria Paula Sassoli Fazan

CAETANO, A. G.; RIBEIRO, T. C.; FILHO, O.A. R. \& FAZAN, V. P. S. Atresia of the coronary sinus ostium to the right atrium with a persistent left superior vena cava. Int. J. Morphol., 27(3):771-776, 2009.

SUMMARY: The coronary sinus has lately assumed an important role in the cardiologic clinic once it has been widely used in invasive procedures of the heart. Commonly, it is used during the electrodes implants for the epimiocardic monitoring of the cardiac rhythm, through a biventricular pace maker. These invasive procedures are not possible in hearts with an atresic coronary sinus ostium. In the presence of this anomaly, another may occur: the development of the "Marchal" vein which is a remaining of the left superior vena cava (LSVC). This happens so that the venous blood from the heart can drain into the right atrium, by a communication between the LSVC and the left brachiocephalic vein. The presence of a LSVC brings difficulties when performing an invasive procedure in order to access the right atrium through the superior vena cava, usually done in the cardiologic clinic. Moreover, the LSVC crossing over the left atrium is vulnerable to cardiovascular surgical interventions, confirmed by clinical reports. In the present study, 400 formalin fixed hearts from male cadavers, aged between 35 and 80 years, were investigated, particularly for the anatomy of the coronary sinus. The obliterated ostium of the coronary sinus to the right atrium associated with a persistent LSVC was present in only one $(0.25 \%)$. We performed a diameter study of these structures since they were dilated due to the venous blood from the heart draining into the right atrium, by a communication between the LSVC and the left brachiocephalic vein. We also perform a literature review of these cases and discuss our finding in relation to its clinical importance.

KEY WORDS: Coronary sinus; Ostial atresia; Persistent left superior vena cava; Congenital heart disease; Cardiac surgery.

\section{INTRODUCTION}

The anatomy of the coronary arteries has been widely explored in the literature while much less attention is given to the cardiac veins and the coronary sinus. The coronary sinus (CS) has lately assumed an important role in the cardiologic clinic once it has been widely used in invasive procedures of the heart. Commonly, it is used during the electrodes implants for the epimiocardic monitoring of the cardiac rhythm, through a biventricular pace maker (Souza et al., 2005). The CS is the major venous drainage vessel of the heart. It is commonly described as a short and wide venous channel, running from left to right, in the posterior part of the atrioventricular groove. It receives the great, middle and small cardiac veins and also the posterior vein of the left ventricle and the oblique vein of the left atrium ("Marchal" vein, a remaining of the left superior vena cava (LSVC) (Agur \& Dalley, 2009). This vein is usually located below the left inferior pulmonary vein.

The CS ostium is oblong in shape and located posterior and inferiorly on the interatrial septum, between the orifices of the inferior vena cava and the tricuspid valve (Hall-Craggs, 1995). When this ostium is not present, this is a rare congenital anomaly named atresia of the CS ostium (Zimand et al., 1999; Jha et al., 2003), considered one of the most rare congenital anomalies of the thoracic circulatory system (Bhatti et al., 2007; Stylianou et al., 2007). This anomaly is commonly

\footnotetext{
* Department of Biological Sciences, Federal University of Triângulo Mineiro, Uberaba, Minas Gerais, Brazil.

** Department of Surgery and Anatomy, School of Medicine of Ribeirão Preto, University of São Paulo, Ribeirão Preto, São Paulo, Brazil.

Support: CNPq (Conselho Nacional de Desenvolvimento Científico e Tecnológico) grants nº 303802/2006-5 and 202079/2007-4, FAPESP (Fundação de Amaparo a Pesquisa do Estado de São Paulo) grants n 06/03200-7 and 06/06362-8, FAEPA (Fundação de Apoio ao Ensino e Pesquisa do Hospital das Clínicas da Faculdade de Medicina de Ribeirão Preto) and FUNEPU (Fundação de Ensino e Pesquisa de Uberaba), Brazil.
} 
associated with others of the cardiocirculatory system, including those of the heart itself (Santoscoy et al., 1996; AlexiMeskishvili et al., 1999). In most cases, this anomaly is considered benign (Santoscoy et al.; Zimand et al.) and usually asymptomatic during the lifespan (von Lüdinghausen \& Lechleuthner, 1988) being an occasional finding during surgical procedures of the heart or necropsies (Jha et al.).

It was previously demonstrated that the complete obliteration of the CS ostium does not impair the venous blood drainage of the heart (von Lüdinghausen \& Lechleuthner). Nevertheless, with this anomaly, an important dilation of the CS develops and might be responsible for organic dysfunctions such as myocardial congestion and heart dilation (Zimand et al.; Kuppusamy \& Balogun, 2004; Jha et al.). These entities are known to be associated to syncope, dyspnea, arrhythmia and Wolff Parkinson White syndrome (Bhatti et al.).

Anomalies of the CS can be obstacles for cardiac pace maker implants (Sterlinski et al., 2008), specially of the electrode for biventricular stimulation, even on a selected population (Auricchio et al.; Souza et al.) and there are reports on the failure of the coronary sinus cannulation in up to $12 \%$ of patients (Butter et al., 2003; Souza et al.). Also, CS anomalies might be associated to alterations of the conduction system of the heart, leading to arrhythmias (Ratliff et al., 2006; Bhatti et al.; Stylianou et al.) and these anomalies should be considered when patients present with inexplicable arrhythmias (Heather et al., 2006).

Atresia of the CS ostium is commonly associated with a persistent left superior vena cava (LSVC) (Salminen et al., 2006; Stylianou et al.) and both, when associated to the univentricular anomaly, are not life compatible (Salminen et al.). Once the CS is responsible for $90 \%$ of the venous blood drainage from the heart, the atresia of its ostium sets the venous blood drainage path backwards though the LSVC, to the left brachiocephalic vein, then to the superior vena cava and finally to the right atrium (Jha et al.; Ratliff et al.; Salminen et al.; Stylianou et al.). The persistent LSVC is described as being associated with systemic embolizations and venous thrombosis (Stylianou et al.) and is clinically important during cardiovascular surgery (Santoscoy et al.; Zimand et al.). The atresia of the CS ostium, associated with a persistent LSVC is known to influence negatively the outcome of CS cannulation (Shahian), or cannulation of the left subclavian (Stylianou et al.), or the internal jugular veins (Kuppusamy \& Balogun, 2004). During surgical procedures for correction of cardiac anomalies, a persistent LSVC is subject to incidental ligation, causing the interruption of the heart venous blood drainage, leading to myocardial ischemia or even myocardial necrosis (Santoscoy et al.).
The objectives of the present study were to investigate and describe the CS anomalies on male adult cadavers' heart, to review the literature and to discuss clinical implications of the findings.

\section{MATERIAL AND METHOD}

This study was performed in 400 hearts from embalmed male donors. The age of death ranged from 35 to 80 years and all specimens were fixed in $10 \%$ formaldehyde solution. The donors have been partially dissected by medical students during the previous years and further heart dissections were done by the authors, with the aid of a D. F. Vasconcellos M-90 surgical microscope. This investigation is based on a 30-years period and all hearts included in the present study were removed from the donors and stored in large plastic containers, immersed in $10 \%$ formalin fixative solution. The hearts were carefully dissected, with special attention to the coronary vessels, prior to the opening of the cardiac chambers. After opening the atria and ventricles, their internal features were studied. The CS ostium was present as an oblong opening on the posterior wall of the right atrium (Fig. 1) and a valve of the CS was present in $85 \%$ of the hearts. In one out of 400 hearts, the CS opening was not present and this anomaly is being described as follows.

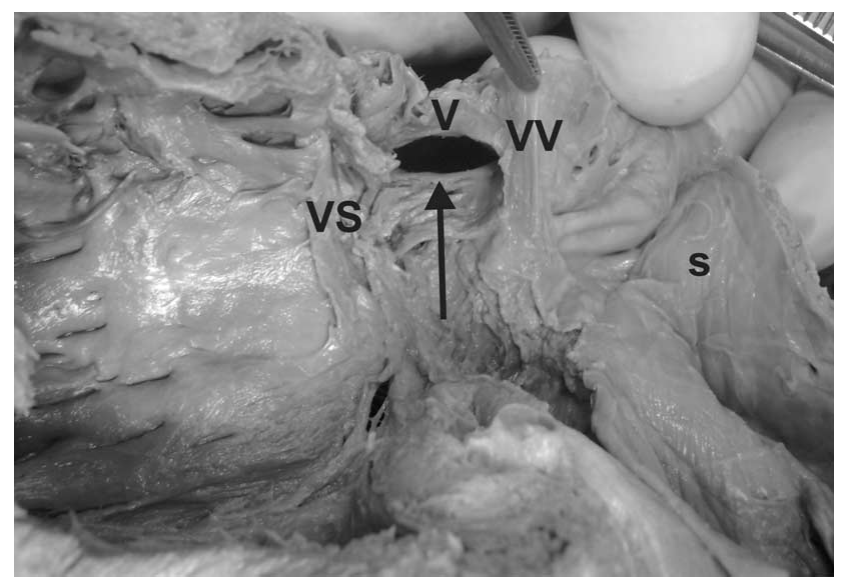

Fig. 1. Dissection from a normal heart, showing the internal surface of the right atrium. Note the coronary sinus ostium (arrow) and its valve (v) opening inferiorly to the inferior vena cava valve (vv), between this valve and the septal cusp of the tricuspid valve (vs). s $=$ posterior wall of the interatrial septum.

\section{RESULTS}

In one of the hearts investigated in the present study, the CS opening into the right atrium was not present (Fig. 2) 

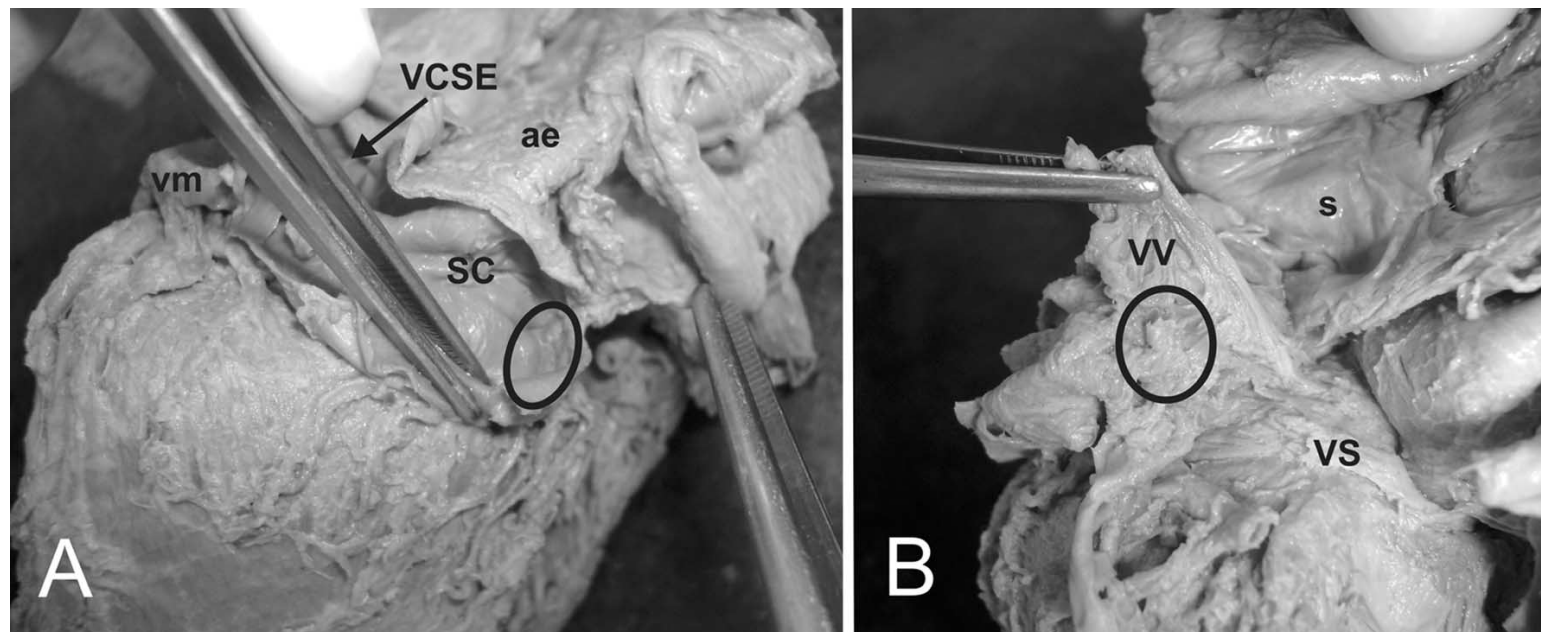

Fig. 2. Dissection from the heart with the atresia of the coronary sinus ostium and a persistent left superior vena cava. A: internal view of the coronary sinus $(\mathrm{sc})$ showing the atresic ostium $(0) . \mathrm{vm}=$ great cardiac vein, $\mathrm{vcse}=$ left superior vena cava, ae = left atrium superior wall. B: Internal view of the right atrium, also showing the atresia of the coronary sinus ostium (0), on the posterior wall of interatrial septum (s). vv = inferior vena cava valve, $\mathrm{s}=$ posterior wall of the interatrial septum, vs = septal cusp of the tricuspid valve.
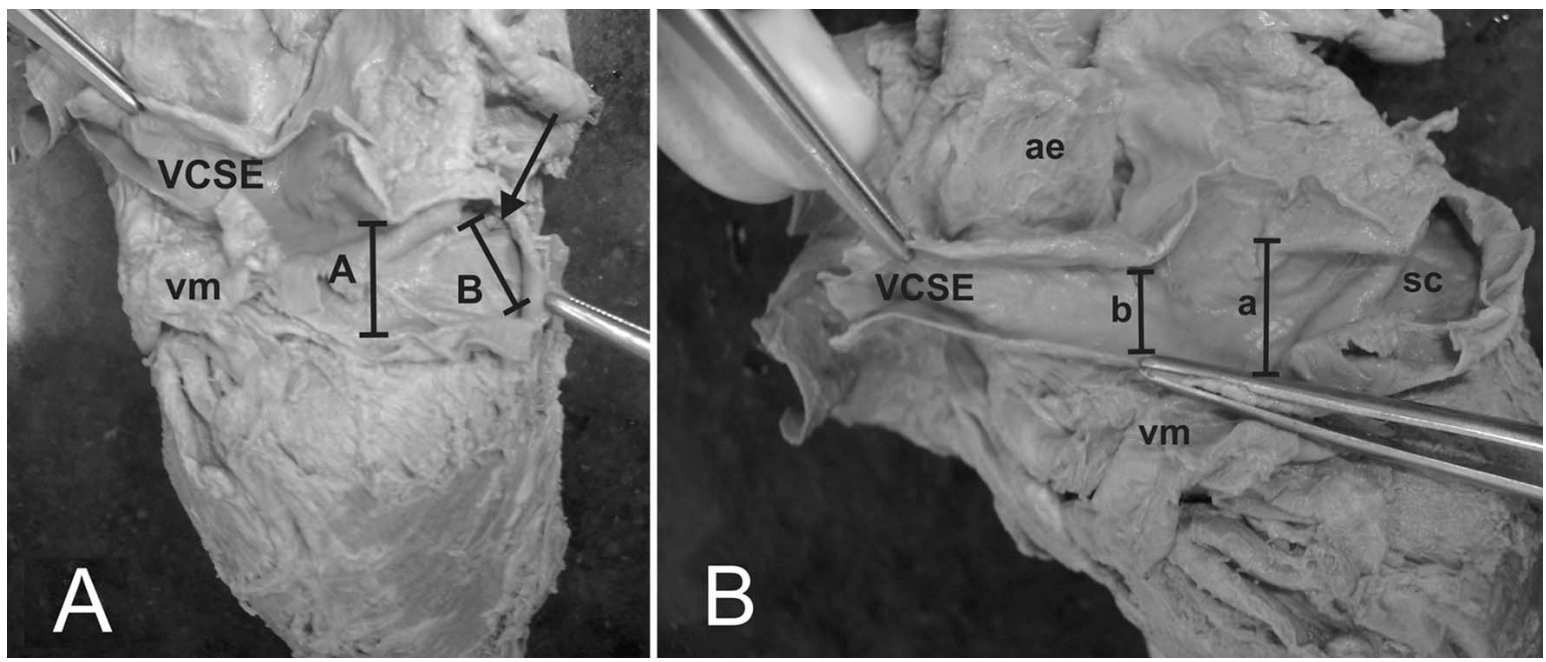

Fig. 3. Dissection from the heart with the atresia of the coronary sinus ostium and a persistent left superior vena cava. A: external view of the dilated coronary sinus (CS) and its dimensions. (A) CS diameter, on the union between the left superior vena cava (vcse) and the great cardiac vein (vm) is $1.7 \mathrm{~cm}$. (B) CS diameter next to the atresic ostium is $1.4 \mathrm{~cm}$. B: External view of the left superior vena cava (vcse), showing its diameters on the union between the coronary sinus ( $\mathrm{sc}$ ) and the great cardiac vein $(\mathrm{vm})(\mathrm{a}=1.8 \mathrm{~cm})$ and on its distal portion $(\mathrm{b}=1.1 \mathrm{~cm})$, where it crosses the superior wall of the left atrium $(\mathrm{ae})$ to reach the brachiocephalic vein.

and the CS was dilated (Fig. 3). We noted the presence of a LSVC, also dilated in diameters (Fig. 3). The With the aid of an electronic digital caliper (range of $0-300 \mathrm{~mm}$, resolution $0.01 \mathrm{~mm}$, Gehaka, SP, Brazil) the diameters of these large vessels were measured and are presented as follows: CS diameter, on the union between the LSVC and the great cardiac vein is $1.7 \mathrm{~cm}$; CS diameter next to the atresic ostium is $1.4 \mathrm{~cm}$, LSVC diameter, on the union between the CS and the great cardiac vein is $1.8 \mathrm{~cm}$ and on its distal portion is $1.1 \mathrm{~cm}$. After measuring the diameters, the vessels were cut longitudinally, to confirm the internal dilatation (Fig. 4).

Despite the absence of the CS opening into the right atrium, the CS formation is normal and its length is of 3.4 $\mathrm{cm}$ (Fig. 4). No other anatomical structures were abnormal or variable in this heart and no cardiac chambers pathology was present in this specimen. 


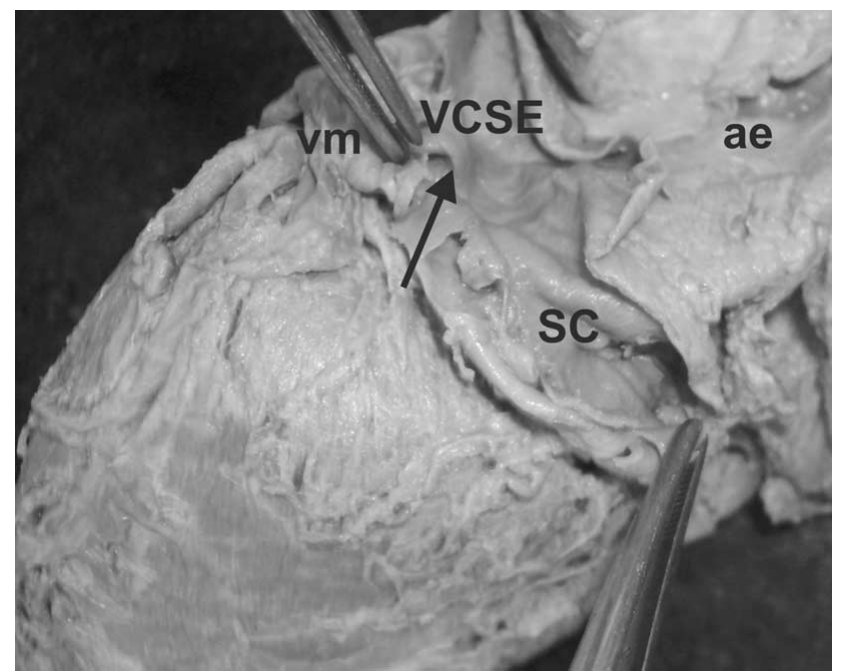

Fig. 4. Dissection from the heart with the atresia of the coronary sinus ostium and a persistent left superior vena cava. Internal view of the union (arrow) between the great cardiac vein (vm) and the left superior vena cava (vcse) forming the coronary sinus (sc). ae = superior wall of the left atrium.

\section{DISCUSSION}

Our results show that the coronary sinus ostium (CSO) is a remarkably stable anatomical structure and when absent, dramatic anomalies of the heart venous system occur. Fortunately, this is a very rare condition and it was present in our casuistic in only $0.25 \%$ (one heart over 400 examined). Despite previous descriptions of this anomaly (Zimand et al.; Jha et al.; Bhatti et al.; Stylianou et al.), to the best of our knowledge, its percentage is being mentioned for the first time in the literature. It is also known that the atresia of the CSO can be associated to other malformations of the cardiocirculatory system (Santoscoy et al.; Alexi-Meskishvili et al.) but this was not the case in the present study. Nevertheless, the association between the atresia of the CSO and a persistent LSVC, as in the present study, is common (Salminen et al.). In the absence of an ostium, the CS must find an alternate route to drain the venous blood from the heart, being the LSVC most likely to provide this route. The atresia of the CSO is considered a benign anomaly of the cardiocirculatory system (Santoscoy et al.; Zimand et al.), which is usually asymptomatic (von Lündinghausen \& Lechleuthner.) or might be presented with mild symptoms (Santoscoy et al.; Zimand et al.). Thus, this anomaly does not cause reduction or impairment of the heart venous blood return and is usually an occasional post-mortem finding (Jha et al.).

Important dilatation of the CS was described in the literature (Zimand et al.; Jha et al.; Kuppusamy \& Balogun;
Stylianou et al.) but information on the diameters of this dilated vessel is being provided for the first time.

Despite considered a benign cardiac anomaly, surgeons must be aware that the atresia of the CSO might account for the lack of success in certain surgical procedures, such as CS cannulation. Butter et al. refers $4 \%$ and Souza et al. refers $7 \%$ of unsuccessful CS cannulations. Nevertheless, since this anomaly is rare, other anatomical variations must be also considered in these surgical procedures, such as an enlarged CS valve (valve of "Thebesius"), found in $62.9 \%$ of patients (Souza et al.) or the presence of a "Vissencius" valve (near the junction of the great cardiac vein and the CS), found in $87 \%$ of cases (Souza et al.). Finally, a persistent LSVC negatively influences the outcome of the left subclavian vein (Shahian et al.; Kuppusamy \& Balogun; Stylianou et al.), because the catheter or electrode would deviate from its course through this vein, not reaching the interior of the right atrium, as expected.

A description of an atresic CSO associated with a persistent LSVC is an alert for the possibility of an asymptomatic anatomic variation, usually not commonly described in the anatomy and or surgical text books, but with an important role in surgical procedures of the heart.

\section{ACKNOWLEDGEMENTS}

We thank Mr. Rui Marcos da Silva, from the Human Anatomy Discipline, Federal University of Triângulo Mineiro, for his excellent technical support while the study was carried out.

CAETANO, A. G.; RIBEIRO, T. C.; FILHO, O. A. R. \& FAZAN, V. P. S. Atresia del ostium del seno coronario en el atrio derecho con una vena cava superior izquierda persistente. Int. $\boldsymbol{J}$. Morphol., 27(3):771-776, 2009.

RESUMEN: El seno coronario recientemente ha asumido un papel importante en la clínica cardiológico, siendo ampliamente utilizado en procedimientos invasivos del corazón. Comúnmente, se utiliza en los implantes de los electrodos para el monitoreo epimiocárdico del ritmo cardiaco, a través de un ritmo biventricular establecido. Estos procedimientos invasivos no son posibles en los corazones con una atresia del ostium del seno coronario. En presencia de esta condición, se puede producir otra anomalía: el desarrollo de la vena de "Marchal" la cual es un vestigio de la vena cava superior izquierda (VCSI). Esto provoca que la sangre venosa del corazón pueda drenar en el atrio derecho, por una comunicación entre la VCSI y la vena braquicefálica izquierda. La presencia de una VCSI trae dificultades a la hora de realizar un procedimiento invasivo con el fin de acceder al atrio derecho a través de la vena 
cava superior, usualmente hecho en la clínica cardiológica. Por otra parte, el cruzamiento de la VCSI sobre el atrio izquierdo es vulnerable en las intervenciones quirúrgicas cardiovasculares, confirmado por informes clínicos. En el presente estudio, 400 corazones fijados en formalina provenientes a cadáveres de sexo masculino, con edades comprendidas entre los 35 y 80 años, fueron investigados, en particular por la anatomía del seno coronario. El ostium obliterado del seno coronario al atrio derecho asociado con una VCSI persistente estuvo presente en sólo una muestra $(0,25 \%)$. Se realizó un estudio del diámetro de estas estructuras dilatadas debido a que la sangre venosa drena desde el corazón hacia el atrio derecho, por una comunicación entre la VCSI y la vena braquicefálica izquierda. También se realiza una revisión de la literatura de estos casos y se discuten nuestros hallazgos en relación con su importancia clínica.

PALABRAS CLAVE: Seno coronario; Atresia ostial; Vena cava superior izquierda persistente; Cardiopatías congénitas; Cirugía cardiaca.

\section{REFERENCES}

Agur, A. M. R. \& Dalley, A. F. Grant's Atlas of Anatomy. Twelfth Ed. Philadelphia, Lippincott Williams \& Wilkins, 2009.

Alexi-Meskishvili, V.; Dähnert, I.; Beyer, E. \& Hetzer, R. Successful total correction of complete atrioventricular canal, total anomalous pulmonary venous drainage and unroofed coronary sinus in an infant. Eur. $J$. Cardiothorac. Surg., 15(1):95-6, 1999.

Auricchio, A.; Klein, H.; Tockman, B.; Sack, S.; Stellbrink, C.; Neuzner, J.; Kramer, A.; Ding, J.; Pochet, T.; Maarse, A. \& Spinelli, J. Transvenous biventricular pacing for heart failure: can the obstacles be overcome? Am. J. Cardiol., 83(5B):136D-42D, 1999.

Bhatti, S.; Hakeen, A.; Ahmad, U.; Malik, M.; Kosolcharoen, P. \& Chang, S. M. Persistent left superior vena cava (PLSVC) with anomalous left hepatic vein drainage into the right atrium: role of imaging and clinical relevance. Vasc. Med., 12(4):319-24, 2007.

Butter, C.; Gras, D.; Ritter, P.; Stellbrink, C.; Fleck, E.; Tockman, B.; Schubert, B.; Pochet, T. \& de Voogt, W. Comparative prospective randomized efficacy testing of different guiding catheters for coronary sinus cannulation in heart failure patients. J. Interv. Card. Electrophysiol., 9(3):343-51, 2003.

Hall-Craggs, E. C. B. Anatomy as a basis for clinical medicine. Third Ed. Philadelphia, Williams \& Wilkins, 1995.
Heather, L. R.; Mohammed, Y.; Wesley, R.; Brent, W. E.; Amer, M.; Gregory, R. \& Ronald, J. M. Persistent left superior vena cava: Case reports and clinical implications. Int. J. Cardiol., 113(2):2426, 2006.

Jha, N. K.; Gogna, A.; Tan, T. H.; Wong, K. Y. \& Shankar, S. Atresia of coronary sinus ostium with retrograde drainage via persistent left superior vena cava. Ann. Thorac. Surg., 76(6):2091-2, 2003.

Kuppusamy, T. \& Balogun, R. Unusual placement of a dialysis catheter: persistent left superior vena cava. Am. J. Kidney Dis., 43(2):365-7, 2003.

Ratliff, H. L.; Yousufuddin, M.; Lieving, W. R.; Watson, B. E.; Malas, A.; Rosencrance, G. \& McCowan, R. J. Persistent left superior vena cava: case reports and clinical implications. Int. J. Cardiol., 113(2):242-6, 2006.

Salminen, J. T.; Hakala, T.; Pihkala, J.; Mattila, I.; Puntila, J. \& Sairanen, H. Coronary sinus orifice atresia with left superior vena cava in patients with univentricular heart. Ann. Thorac. Surg., 81(5):16-7, 2006.

Santoscoy, R.; Walters 3rd, H. L.; Ross, R. D.; Lyons, J. M. \& Hakimi, M. Coronary sinus ostial atresia with persistent left superior vena cava. Ann. Thorac. Surg., 61(3):879-82, 1996.

Shahian, D. M. Retrograde coronary sinus cardioplegia in the presence of persistent left superior vena cava. Ann. Thorac. Surg., 54(6):1214-5, 1992.

Souza, F. S. O.; Braile, D. M.; Vieira, R. W.; Rojas, S. O.; Mortati, N. L.; Rabelo, A. C. \& Oliveira, S. A. Technical aspects of lead implantation for left ventricle pacing through the coronary sinus, using anatomic radiology and intracavitary electrogaphy in the cardiac resynchronization therapy. Braz. J. Cardiovasc. Surg., 20(3):301-9, 2005.

Sterlinski, M.; Sosnowski, C.; Zajac, D.; Ruzyllo, W. \& Szwed, H. Is coronary vein angioplasty necessary to provide cardiac resynchronization in selected patients? A case report. Europace, 10(9):1116-8, 2008.

Stylianou, K.; Korsavas, K.; Voloudaki, A.; Patrianakos, A.; Vardaki, E.; Tzenakis, N. \& Daphnis, E. Can a left internal jugular catheter be used in the hemodialysis of a patient with persistent left superior vena cava? Hemodial. Int., 11(1):42-5, 2007. 
CAETANO, A. G.; RIBEIRO, T. C.; FILHO, O. A. R. \& FAZAN, V. P. S. Atresia of the coronary sinus ostium to the right atrium with a persistent left superior vena cava. Int. J. Morphol., 27(3):771-776, 2009

von Lündighausen, M. \& Lechleuthner, A. Atresia of the right atrial ostium of he coronary sinus. Acta Anat., 131(1):81-3, 1988.

Zimand, S.; Benjamin, M. F.; Frand, M.; Mishaly, D.; Smolinsky, A. K. \& Hegesh, J. Left superior vena cava to the left atrium: do we have to change the traditional approach? Ann. Thorac. Surg., 68(5):1869-71, 1999.
Correspondence to:

Valéria Paula Sassoli Fazan

Associate Professor

Department of Surgery and Anatomy

School of Medicine of Ribeirão Preto

USP, Av. Bandeirantes 3900

Ribeirão Preto, 14049-900. SP.

Brazil.

Phone: + 5516 3602-2501

FAX : + $55163633-0017$

Email:vpsfazan@yahoo.com.br vpsfazan@gmail.com

Received: 02-01-2009

Accepted: 12-05-2009 